\title{
PREÂMBULOS DAS CONSTITUIÇÕES DO BRASIL
}

\author{
Dalmo de Abreu Dallari \\ Professor Titular da Faculdade de Direito da Universidade de \\ São Paulo e Vice-Presidente da Comissão Internacional de Juristas
}

Resumo:

O Estado exerce influência fundamental na vida de todas as pessoas e de todos os grupos humanos. Esse é um fato do nosso tempo, independente da vontade de cada, não havendo uma só pessoa, rica ou pobre, poderosa ou humilde, que possa ficar totalmente livre da influência do Estado. Por esse motivo, o Estado é tema de extraordinária relevância em todos os estudos e pesquisas, de caráter teórico ou visando objetivos práticos, relativos aos comportamentos humanos. Assim, também, para a tomada das decisões de maior importância, de caráter político, econômico ou social, é absolutamente necessário considerar o Estado, como atender às suas determinações ou subtrair-se delas, como usá-lo para auferir benefícios ou para se defender de ameaças ou agressões de muitas espécies. Por todos esses motivos, é constante a preocupação com a evolução do Estado, com o papel que ele poderá representar na história da Humanidade, em futuro próximo ou remoto. Assim sendo, este trabalho é baseado em experiência histórica e considerando as circunstâncias presentes, levando em conta os dados resultantes de estudos e pesquisas em múltiplas áreas científicas que se ocupam dos comportamentos humanos, é um esforço de predição quanto ao futuro do Estado. Não é uma proposta para o futuro nem uma especulação abstrata, mas, diferentemente disso, é uma tentativa de predição do futuro do Estado com bases científicas.

\section{Abstract:}

The State exerts primordial influence in the life of all the people and all the human groups. This is a fact of our time, independent of the will of each one, not having anyone, rich or poor, powerful or humble person, who can be total free of the influence of the State. For this reason, the State is subject of extraordinary relevance in all studies and researches, of character theoretical or aiming practical purpose, concerning to the human behaviors. Thus, also, for the taking of the decisions of bigger importance, of political, economic or social character, it is absolutely necessary to consider the State, as to take care of to its determination or to deduct themselves from them, as to 
use it to gain benefits or to defend of threats or aggressions of many species. For all these reasons, the concern with the evolution of the State is constant, with the paper that it will be able to represent in the history of the Humanity, in next or remote future. Thus being, this work is based on historical experience and considering the actual circumstances, leading in account the resultant data of studies and research in multiple scientific areas which occupy of the human behaviors, are an effort of prediction about the future of the State. It is not a proposal for the future nor an abstract speculation, but, differently of this, it is an attempt of prediction of the future of the State with scientific bases

Unitermos: Preâmbulo; Constituição; História Constitucional Brasileira; Brasil: constituições; Eficáciạ das normas constitucionais

\section{I . Preâmbulos reveladores}

A simples leitura dos Preâmbulos das constituições que o Brasil já teve é suficiente para revelar, em suas linhas fundamentais, a história constitucional brasileira. Essa revelação já resulta clara pelo fato de que no início de cada Preâmbulo se encontra a identificação da instituição, do órgão ou do personagem que fez a Constituição, por onde já se tem a idéia das circunstâncias políticas em que cada uma das constituições brasileiras foi gerada.

Pelo exame dos Preâmbulos verifica-se que das oito constituições que o Brasil já teve apenas quatro foram elaboradas por uma Assembléia Constituinte. É também expressivo e revelador, demonstrando certa coerência e contribuindo para a percepção das circunstâncias políticas, a peculiaridade de que só os Preâmbulos daquelas constituições feitas por método democrático fazem referências à democracia e à liberdade como objetivos a serem atingidos com apoio na Constituição.

Quem tiver como referência apenas o texto dos Preâmbulos poderá chegar a conclusões equivocadas. Com efeito, aquele dado - a referência expressa à democracia e à liberdade - poderia ser tomado como indicador da autoridade e da relevância que as lideranças políticas predominantes no momento da edição pretendiam dar a cada uma das constituições ou que estas adquiriram em seguida. Entretanto, o exame da evolução dos acontecimentos não permite que se generalize essa ligação, considerando-a válida para todos os casos. Na realidade, como será esclarecido com mais pormenores quando for feita a análise do conteúdo dos Preâmbulos, ressaltando alguns pontos básicos das 
circunstâncias políticas em que surgiu cada Constituição e das que se seguiram a elas, houve constituições que foram igualmente decretadas por lideranças democráticas ou antidemocráticas e que, no entanto, influíram de modo diferente quanto ao reconhecimento e respeito dos direitos fundamentais ou a alguns deles.

Assim, também, a origem democrática ou autoritária revelada pelo Preâmbulo não tem ligação com a duração das constituições. Basta assinalar que a Constituição de 1824, imposta por um decreto imperial, durou 65 anos, em contraste com a de 1934, elaborada por uma Assembléia Constituinte eleita pelo povo, que durou apenas três anos. A de 1891, também produzida por uma Assembléia eleita pelo povo, foi mantida por 39 anos, ao passo que a de 1967. feita por método antidemocrático, teve duração de apenas dois anos.

Como última observação preliminar, é interessante assinalar que no Brasil somente agora, depois da elaboração da Constituição de 1988, é que se começou a dar importância ao Preâmbulo da Constituição, reconhecendo seu caráter de preceito jurídico e, portanto, a exigência jurídica de respeitá-lo e de tê-lo em conta na interpretação dos artigos da Constituição e no controle da constitucionalidade das leis e dos atos jurídicos. Na realidade, os Preâmbulos sempre foram vistos como simples fórmula retórica, desligada do corpo da Constituição e sem qualquer eficácia jurídica. Nas ocasiões de decretação autoritária de uma nova Constituição o Preâmbulo foi utilizado como uma espécie de manifesto político, por meio do qual se procurou justificar a imposição de uma nova Carta Constitucional, tomando como pretexto o interesse do povo.

A exceção a essa prática ocorreu com a Constituição de 1967, o que se explica pelo fato de que ela foi, na realidade, uma imposição autoritária mas com a pretensão de simular uma decisão democrática, tendo contado com a participação, embora muito restrita, de quase todo o Parlamento nacional. Por esse motivo, ninguém quis assumir a responsabilidade de explicar no Preâmbulo a razão pela qual a Constituição democrática vigente até então, a de 1946, que poderia ser aperfeiçoada, através de emendas constitucionais, estava sendo substituída por outra.

Um sinal muito expressivo da pouca autoridade atribuída aos Preâmbulos e de sua irrelevância na prática juridica brasileira é o fato de que as inúmeras obras publicadas por constitucionalistas, comentando as constituições brasileiras, nunca incluíram comentários ou análises dos Preâmbulos. O mesmo se verifica nas obras doutrinárias de Direito Constitucional brasileiro, que sistematicamente ignoraram os Preâmbulos. Isso demonstra que mesmo para os constitucionalistas o Preâmbulo não 
era considerado parte da Constituição ou pelo menos uma diretriz para a interpretação e aplicação dos artigos da Constituição.

Essa concepção começou a mudar a partir da vigência da Constituição de 1988, como expressão de un novo constitucionalismo, que já chegou também ao País, devendo ser reconhecida, para essa mudança, a grande influência exercida, sobretudo, pelo constitucionalista português José Joaquim Gomes Canotilho. Outros juristas eminentes também contribuíram para essa atualização do pensamento constitucional brasileiro, mas a obra de Canotilho foi, sem dúvida, a de maior influência, provavelmente pela grande repercussão que teve no Brasil a nova Constituição de Portugal, de 1976, como também pelo fato de ter sido publicada em lingua portuguesa.

II. Os Preâmbulos das constituições passadas

\section{Constituição de 1824}

A primeira Constituição brasileira é do ano de 1824. Proclamada solenemente a independência do Brasil, em 7 de setembro de1822, rompendo os laços coloniais com Portugal, assumiu o Governo brasileiro o então príncipe regente Dom Pedro, filho do rei português Dom João VI. Influenciado por líderes políticos brasileiros, como também pelo fato de que em Portugal havia ocorrido uma revolução liberal, tendo como resultado a conversão da Monarquia Absoluta portuguesa em Monarquia Constitucional, Dom Pedro definiu o Brasil como Império, fez-se coroar com o título de Dom Pedro I, imperador do Brasil, e pouco depois convocou uma Assembléia Constituinte.

Eleita a Constituinte em 1823, logo se verificou que ela adotava rumos bem diferentes daqueles desejados pelo imperador, que tinha nascido e sido educado numa Corte absolutista. Não tolerando as divergências, sobretudo quanto à extensão dos seus poderes, e considerando-se desrespeitado, o imperador dissolveu a Constituinte, mas preocupado em manter o compromisso de dar uma Constituição ao Brasil mandou que um grupo de políticos eminentes, de sua inteira confiança e mais afinados com seu pensamento, elaborasse um projeto.

Para atenuar o caráter de imposição antiliberal, o imperador pediu e obteve a aprovação de algumas Câmaras Municipais e depois disso, em 25 de março de 1824 , publicou um decreto pondo em vigor o projeto elaborado a seu pedido. Nesse 
projeto estavam presentes alguns preceitos liberais, inclusive uma declaração de direitos e a separação de poderes, ao mesmo tempo em que eram assegurados amplos poderes ao imperador, que em relação a determinadas matérias teria poder absoluto. Assim nasceu a primeira Constituição brasileira, com o seguinte:

Preâmbulo

Dom Pedro I, Por Graça de Deus, e Unânime Aclamação dos Povos, imperador Constitucional e Defensor Perpétuo do Brasil: Fazemos saber a todos os Nossos Súditos, que tendo-Nos requerido os Povos deste Império, juntos em Câmaras, que Nós quanto antes jurássemos e fizéssemos jurar o Projeto de constituição, que haviamos oferecido às suas observações para serem depois presentes à Nova Assembléia Constituinte; mostrando o grande desejo, que tinham, de que ele se observasse já como constituição do Império, por lhes merecer a mais plena aprovação, e dele esperarem a sua individual, e geral felicidade Politica: Nós Juramos o sobredito Projeto para o observarmos e fazermos observar, como constituição, que d'ora em diante fica sendo deste Império; a qual é do teor seguinte: Em Nome da Santissima Trindade.

Como se verifica, Dom Pedro I assume a autoria do projeto, mas o Preâmbulo contém uma ambigüidade, quando afirma que os povos do Império "juntos em Câmaras" pediram que o imperador jurasse o projeto que ele havia oferecido para receber observações, para serem depois apresentadas à nova Assembléia Constituinte. Diz também o Preâmbulo que as Câmaras aprovaram integralmente o projeto e pediram que ele fosse imediatamente convertido em constituição do Império, para "geral felicidade Politica". As Câmaras aí referidas de modo muito vago foram apenas algumas Câmaras Municipais, que, sem outra perspectiva, decidiram manifestar sua concordância com os termos do projeto, sugerindo que ele fosse logo publicado e posto em vigor como Constituição.

Na realidade, não havia outra possibilidade para a limitação do poder absoluto do imperador e a conversão do Brasil em Monarquia Constitucional, o que, naquela circunstância, era uma aspiração política generalizada entre as lideranças políticas brasileiras. A referência a uma "Nova Assembléia Constituinte", à qual teria a intenção de submeter o novo projeto, era apenas um artifício para sugerir o espírito democrático do imperador, pois tendo em conta o péssimo desfecho da primeira Assembléia ninguém poderia acreditar que o imperador corresse o risco de convocar uma nova. 
Finalmente, é importante notar que no final do Preâmbulo se diz que a constituição será "do teor seguinte", ou seja, terá a redação que vem depois, o que deixa evidente que o Preâmbulo não faz parte da Constituição, não podendo, assim, ser invocado como norma constitucional, vinculante e dotada de eficácia jurídica. Esse procedimento seria adotado em todas as constituições brasileiras que vieram depois. Note-se, afinal, que o imperador decreta a Constituição "em nome da Santíssima Trindade". Aí também se contém uma ambigüidade, pois tal afirmação não foi o sinal de uma intensa religiosidade do imperador, que, na realidade, nunca demonstrou grande fervor religioso. Pode-se interpretar essa invocação à Santíssima Trindade como artifício político, pois agradaria à Igreja católica, que exercia forte influência no panorama político brasileiro, mas, ao mesmo tempo, aquela referência lembraria que ao decretar a Constituição o imperador estaria exercendo um "direito divino" o que estaria de acordo com sua formação absolutista e seria um forte apêlo à obediência incondicional pelo povo, afirmando o "caráter sagrado" da Constituição.

Apesar dessa retórica, o imperador encontrou grande resistência entre as lideranças políticas brasileiras, devendo-se observar que a imensidão do território brasileiro; cuja ocupação se fez a partir de pontos isolados, favorecendo uma grande diversidade econômica e social, sem a possibilidade da presença efetiva do Governo central, resultou na formação de muitos núcleos políticos regionais, com interesse próprio. Tais circunstâncias dificultaram muito a afirmação da autoridade nacional de Dom Pedro I, que em 1831 foi obrigado a abdicar, deixando em seu lugar seu filho com apenas oito anos de idade, que alguns anos depois assumiu o Governo do Império com o título de Dom Pedro II. Apesar dessas graves perturbações, a Constituição foi mantida e em grande parte foi efetivamente aplicada, tendo sofrido algumas emendas significativas, visando fortalecer as lideranças políticas regionais e estabelecer o equilíbrio entre os poderes do imperador e os do Parlamento. Não obstante as limitações, pode-se dizer que houve coerência entre o Preâmbulo, a Constituição e as circunstâncias políticas.

\section{A Constituição de 1891}

No dia 15 de novembro de 1889 , em conseqüência de um conjunto de circunstâncias políticas, econômicas e sociais e por decisão de uma coligação de forças extremamente heterogêneas, foi proclamada a República no Brasil. Nesse mesmo dia assumiu o poder um Governo Provisório, que publicou uma proclamação anunciando a eleição de uma Assembléia Nacional Constituinte, que deveria elaborar uma 
Constituição "republicana e federativa", refletindo as idéias de um movimento político de expressão nacional.

Embora com sérias limitações, a Assembléia Constituinte foi eleita pelo povo. Não foi dado o direito de voto às mulheres nem aos analfabetos, cujo número era muito elevado na população brasileira, utilizando-se o sistema de voto aberto, nãosecreto, o que facilitou a intimidação dos eleitores mais pobres e criou constrangimento para os que, do ponto de vista econômico ou ainda para terem acesso a posições sociais mais elevadas, dependiam de lideranças políticas. Apesar dessas e de outras limitações, os constituintes foram eleitos e houve liberdade para que as conviçcões políticas fossem manifestadas, devendo-se ressaltar que as divergências de caráter político eram, basicamente, a expressão de conflitos de interesses. De um lado estavam os conservadores, na grande maioria ligados à propriedade da terra e a privilégios que vinham dos tempos coloniais ou tinham sido adquiridos durante o período monárquico. De outro lado estavam os que se qualificavam como liberais, influenciados pelos autores que haviam inspirado as revoluções burguesas dos séculos XVII e XVIII, bem como pela experiência política dos EUA.

Desde o ano de 1870 vinla sendo desenvolvida uma campanha a favor da República, tendo sido criados núcleos republicanos em várias Províncias brasileiras, nunca se tendo chegado a uma integração nacional desses núcleos. Essa impossibilidade de unificação era o reflexo de interesses regionais, diferenciados e muitas vezes conflitantes, o que ficou muito evidente pelas divergências, muito agudas e expressamente maniféstadas, quanto à adoção do Federalismo. Em várias Províncias foram publicados Manifestos Republicanos, mas enquanto as Províncias do Sul propunham a organização federativa, de modelo norte-americano, como a solução natural e conveniente para a integração brasileira, nas regiões Norte e Nordeste, mais atrasadas e com organização social semifeudal e também mais dependentes do Governo central, a proposta federalista era repudiada com grande veemência. Os republicanos dessas regiões consideravam o Federalismo um risco para a unidade brasileira e uma forma de outorgar plena liberdade às Províncias mais ricas e desenvolvidas, comprometendo a solidariedade nacional.

Nesse ambiente de divergências foi eleita e instalada a Assembléia Nacional Constituinte, que debateu amplamente as principais propostas para a Constituição e, no ano de 1891, concluiu sua tarefa. Nasceu, assim, a primeira Constituição republicana brasileira, que foi promulgada e publicada com o seguinte: 
Preâmbulo

Nós, os Representantes do Povo Brasileiro, reunidos em Congresso Constituinte, para organizar um regime livre e democrático, estabelecemos, decretamos e promulgamos a seguinte constituição da República dos Estados Unidos do Brasil.

O primeiro ponto a ressaltar nesse Preâmbulo é a afirmação da legitimidade dos constituintes, por terem sido eleitos pelo povo brasileiro. Aí está implícito o reconhecimento da soberania popular, pois foi em nome do povo e como seus representantes que os constituintes elaboraram a Constituição. Coerente com os ideais republicanos, o Congresso Constituinte "estabeleceu, decretou e promulgou" a Constituição, exercendo um direito cujo titular é o povo, do qual os membros do Congresso eram representantes. Ao mesmo tempo em que há esse reconhecimento de que os constituintes eram apenas representantes e não elaboraram a Constituição em seu próprio nome ou no exercício de um direito individual de cada um, há também, nesse Preâmbulo, a lembrança de que a Constituição era expressão da vontade do povo e daí vinha sua autoridade. O principal interessado na obediência à Constituição era o povo, cuja vontade ela expressava.

Outro ponto fundamental desse breve Preâmbulo é a afirmação de que os representantes tinham sido eleitos "para organizar um regime livre e democrático" Nessa afirmação está a rejeição à monarquia, ao absolutismo e a todas as formas de tirania, mas também a afirmação da opção por um tipo de sociedade na qual os indivíduos deveriam ter plena liberdade individual, ao lado da liberdade econômica, sem riscos e limitações para a propriedade privada e para o uso dos bens. Isso tudo fazia parte do ideário liberal e republicano. É importante lembrar, também, que o Brasil tinha mantido legalmente a escravatura até 13 de maio de 1888 , o que tinha contribuído para que os ex-proprietários de escravos, apesar de serem conservadores, se aliassem aos republicanos, especialmente porque não tinham sido indenizados pela perda dos escravos.

A par disso, deve-se observar que, embora com divulgação apenas entre alguns intelectuais e sem grande aceitação, já tinham chegado ao Brasil as idéias socialistas e anarquistas. Essas idéias não chegaram a ser debatidas na Constituinte, mas provavelmente sua lembrança também exerceu alguma influência para que alguns constituintes quisessem fazer a afirmação expressa da liberdade como fundamento da sociedade. Lembre-se, a propósito, que era recente a publicação da encíclica "Rerum novarum" do papa Leão XIII, o que havia despertado em amplos setores da Igreja católica, muito influente no Brasil, o temor de que a "questão social" pudesse despertar idéias revolucionárias inconvenientes para a liberdade econômica e religiosa. 
Outro ponto muito significativo desse Preâmbulo é a referência à Constituição da "República dos Estados Unidos do Brasil", por onde fica patente a grande influência exercida pelos EUA. Essa influência foi expressamente mencionada por vários constituintes em muitas oportunidades. Foi especialmente importante, a esse respeito, o desempenho do constituinte Ruy Barbosa, advogado de grande prestígio que havia participado ativamente da campanha abolicionista e que era profundo conhecedor da história política e da Constituição dos EUA. Em sua opinião, a riqueza e o poderio dos EUA, visíveis apesar de seu pouco envolvimento no plano internacional, deviam-se, em grande parte, à sua Constituição, republicana, com separação dos Poderes, e federativa.

Quanto à opção republicana havia amplo consenso, o que se confirma pelo fato de que não chegou a ocorrer luta no Brasil para a implantação da República, não tendo havido também qualquer movimento significativo, buscando restaurar a monarquia. No tocante à opção federativa, houve alguns debates mas os federalistas tinham grande maioria na Constituinte. Ao lado disso, existe o fato de que o manifesto publicado por expressivas lideranças civis e militares, em 15 de novembro de 1989 , proclamando a República no Brasil, já dizia que a futura Constituição seria "republicana e federativa". condicionando, desse modo, a ação dos constituintes.

O que se decidiu, então, foi transformar as antigas Províncias brasileiras em Estados autônomos e dizer que estes se uniam para formar o Estado brasileiro. Era uma ficção, porque o Brasil já existia como Estado, mas foi uma forma de tornar mais evidente a utilização do modelo norte-americano. Na opinião de muitos constituintes a fórmula "Estados Unidos do Brasil" era a que mais convinha para a organização política de uma sociedade livre e democrática. Desse modo, embora muito sintético o Preâmbulo expressou as idéias políticas básicas predominantes na Constituinte, devendo-se admitir que aquelas eram as idéias predominantes entre os brasileiros que tiveram o direito de votar para eleger os constituintes.

\section{A Constituição de 1934}

A Constituição de 1891 durou até 1930, quando um golpe de Estado pôs fim à Primeira República brasileira. Nos primeiros anos de vigência essa constituição só foi aplicada em parte, pois embora a Constituição estabelecesse que o presidente da República seria eleito pelo povo, os constituintes decidiram, no final dos trabalhos, que o primeiro presidente seria eleito pela Constituinte e no final de seus trabalhos escolheu o general Deodoro da Fonseca, que havia sido signatário da Proclamação da República, para presidente. 
Por motivo de fortes divergências políticas, manifestadas em vários pontos do país, o presidente da República, inexperiente e sem força para embates políticos, renunciou ao mandato antes de ter chegado à metade do período presidencial e quem assumiu a Presidência foi o vice-presidente, Floriano Peixoto, também militar, mas com bastante energia e com vocação para o exercício do poder. Foi contestada a constitucionalidade de sua permanência no cargo, uma vez que, naquela circunstância, era prevista na Constituição a realização de novas eleições e o vice-presidente só deveria ficar no cargo até a escolha, pelo povo, do novo presidente. Mas Floriano Peixoto permaneceu na chefia do Governo, caracterizando-se formalmente, quanto ao Poder Executivo, uma ditadura. Isso restringiu bastante a aplicação da Constituição, mas não impediu que o Legislativo continuasse funcionando e fizesse várias leis necessárias à instalação do regime republicano.

No final do mandato de Floriano Peixoto realizaram-se eleições, encerrando-se o que foi chamado de "período militar" da Primeira República. Esta foi bastante conturbada, pois nos primeiros anos do século XX teve início a criação de um parque industrial no Brasil, especialmente no Estado de São Paulo. Já no final do século XIX haviam chegado ao Brasil muitas famílias de imigrantes europeus, contratados para substituir os trabalhadores escravos na agricultura. Com essas famílias chegaram novas idéias e novos costumes, sendo especialmente importante assinalar que muitos desses imigrantes, sobretudo italianos e espanhóis, passaram a viver nas cidades e a trabalhar na indústria. Com eles chegou a noção de direito dos trabalhadores.

A Primeira República brasileira foi marcada por muitos conflitos, tendo havido várias intervenções federais em alguns Estados-membros, chegando-se a afirmar no Parlamento nacional que alguns Estados estavam confundindo autonomia com soberania. Cada Estado adotou sua própria Constituição e várias constituições estaduais continham dispositivos que eram contrários à Constituição federal. Havia a novidade da organização federativa, gerando problemas, ou pela inexperiência ou porque as antigas lideranças provinciais, convertidas após 1891 em lideranças estaduais, queriam mais liberdade de ação e não aceitavam restrições e sacrifícios impostos pelo Governo central para proteger os Estados menos desenvolvidos.

A primeira experiencia brasileira de federalismo, que durou de 1891 a 1930 revelou aspectos positivos e negativos. Os Estados das regiões Sul e Centro-Sul aproveitaram a autonomia para acelerar seu desenvolvimento econômico e social. A influência dos imigrantes foi significativa nessas regiões, em vários sentidos. Assim, por exemplo, foi inevitável o estabelecimento de novas condições nas relações de 
trabalho e apesar da repressão policial surgiram os sindicatos e se desenvolveu a noção de direitos dos trabalhadores.

A par disso, em poucas décadas os descendentes dos imigrantes começaram a ter acesso a cargos públicos e conseguiram uma ascensão social que lhes permitiu ocupar posições que anteriormente eram reservadas às elites tradicionais. Desse modo, nos Estados mais desenvolvidos foi inevitável certa modernização, favorecendo a mobilidade social, enquanto nos outros Estados a autonomia favoreceu a manutenção de grupos oligárquicos privilegiados, com absoluto domínio da vida política. Nessa perspectiva pode-se dizer que o federalismo contribuiu para a preservação dos desníveis regionais e para a ampliação dos desníveis sociais.

Nos centros em que era maior a concentração de trabalhadores urbanos, como Rio de Janeiro e São Paulo, surgiram no início do século XX várias organizações de trabalhadores e com elas as primeiras greves, violentamente reprimidas pelas forças policiais, tornando-se palavra de ordem dos governos a expressão "a questão social é questão de Polícia" Assim, a liberdade e a democracia, previstas no Preâmbulo da Constituição, sofreram sérias restrições, especialmente quanto às camadas mais modestas da população e para aqueles que falavam e pretendiam agir em favor da liberdade e da democracia.

A manutenção do sistema de voto aberto, com a manutenção da marginalização das mulheres e dos analfabetos, além de outros vícios eleitorais, tudo isso tornou bem precária a democracia. No final da década de 20 os graves problemas sociais e políticos levaram à aglutinação de forças políticas heterogêneas, incluindo aspirações à moralidade pública, à autenticidade eleitoral e à Justiça social. E assim, em 1930, um golpe de Estado encerrou essa fase republicana e constitucional.

Instalado um Governo provisório, chefiado por Getúlio Vargas, teve início um período de Governo ditatorial, que logo começou a ser contestado por muitas das forças políticas que haviam colaborado para sua implantação. A contestação à ditadura foi mais forte no Estado de São Paulo, onde já havia um significativo desenvolvimento industrial e uma liderança política muito ativa. Começou-se a exigir a realização de eleições e a convocação de uma Assembléia Nacional Constituinte, tendo havido, inclusive, um movimento armado que foi denominado "Revolução Constitucionalista", através do qual o Estado de São Paulo, com um exército de voluntários e o apoio de sua Força Policial estadual, enfrentou o Governo federal. Esse movimento acabou sendo dominado pelas forças federais, mas o resultado desejado foi conseguido e no ano de 1933 foi convocada a Assembléia Nacional Constituinte e seus membros foram eleitos pelo povo. 
A Constituinte, de 1934, apresentou várias inovações de grande importância, a começar pelo novo sistema eleitoral implantado pelo Governo provisório e que já foi utilizado para a eleição dos constituintes. As mulheres receberam o direito de votar e de serem eleitas e o voto passou a ser secreto, o que deu enorme independência ao eleitorado. Pela primeira vez o Brasil teve uma Assembléia Constituinte, na qual estava presente a mulher, ao lado de representantes dos operários, declaradamente a favor do socialismo. Ao mesmo tempo, refletindo as propostas políticas em voga na Europa, havia corporativistas, influenciados sobretudo pelos acontecimentos da Itália, e adeptos de um nacionalismo elitista que fazia lembrar o nazismo. Mas estavam presentes também os representantes das elites tradicionais, apoiadas no latifúndio e na atividade rural, bem como representantes do capitalismo industrial e financeiro.

Essa Assembléia Nacional Constituinte aprovou, em 1934, a nova Constituição do Brasil, que foi apresentada com o seguinte:

Preâmbulo

Nós, os representantes do Povo Brasileiro, pondo a nossa confiança em Deus, reunidos em Assembléia Nacional Constituinte para organizar um regime democrático, que assegure à Nação a unidade, a liberdade, a Justiça e o bem-estar social e econômico, decretamos e promulgamos a seguinte Constituição da República dos Estados Unidos do Brasil.

Esse Preâmbulo, embora sintético, é revelador da heterogeneidade de forças políticas presentes na Assembléia e mostra que houve um esforço para conciliar idéias, crenças, interesses e objetivos bastante diferenciados. O ponto comum, em relação ao qual todos estavam de acordo e que se considerou importante ressaltar desde logo, foi a afirmação da legitimidade da Assembléia Nacional Constituinte, que reunia representantes do povo brasileiro. Isso deveria assegurar a autoridade da Constituição e sua supremacia, o que naquele momento era importante deixar expresso, porque a Assembléia Constituinte tinha sido, pode-se dizer, imposta ao governo provisório chefiado pelo presidente Getúlio Vargas, que se considerava intérprete legítimo dos interesses nacionais porque tinha chegado ao Governo com o apoio de um leque de opiniões muito amplo e diversificado.

A expressão "confiança em Deus" que se encontra no Preâmbulo foi inserida, muito provavelmente, por influência dos constituintes católicos tradicionalistas, mas também daqueles que já estavam temerosos do crescimento do comunismo, do 
avanço "da Rússia" como diziam no Brasil os padres católicos e também a Imprensa conservadora, que expressava o pensamento e o temor dos grandes proprietários. É oportuno lembrar que naquele momento já existia no Brasil um Partido Comunista, que estava crescendo e começava a entrar em conflito com os militantes da Ação Integralista, versão abrasileirada do nazismo.

Conforme consta do Preâmbulo, os constituintes tinham recebido do povo brasileiro a incumbência de organizar um regime democrático, o que deixava clara a rejeição da ditadura. Entretanto, refletindo e procurando conciliar as diferentes correntes de pensamento político e os diferentes interesses representados na Constituinte, o Preâmbulo faz uma enumeração de objetivos específicos, compreendidos na idéia de regime democrático. A referência expressa à "unidade" é um reflexo das lutas políticas que tinham descambado para a luta armada. As lideranças do Estado de São Paulo tinham sido acusadas de "separatistas", havendo quem afirmasse que a exigência da convocação de uma Assembléia Constituinte tinha sido apenas um pretexto, pois o objetivo era separar o Estado de São Paulo do resto do Brasil. Em tais circunstâncias, a afirmação da unidade como objetivo nacional era importante.

A liberdade continuava sendo o primeiro dos direitos para a burguesia liberal, mas todós estavam de acordo quanto à sua necessidade. As referências à Justiça e ao bem-estar social e econômico são, de um lado, o reflexo de novas influências que haviam despertado novas aspirações e, de outro lado, tinham a intenção de demonstrar que não era necessário fazer uma revolução comunista para que houvesse Justiça e bem-estar social e econômico. Pretendia-se mostrar ao povo que todos, inclusive as elites tradicionais, estavam de acordo quanto a esses objetivos e que se dispunham a trabalhar para sua realização, tanto assim que eles estavam expressos no Preâmbulo da Constituição. Esse referência abstrata a tais objetivos, feita no Preâmbulo, não gerava direitos nem obrigações e poderia ter efeito político, acalmando os insatisfeitos.

Finalmente, a reiteração da expressão "Estados Unidos do Brasil" repetindo o que tinha sido feito, em 1891, era uma reafirmação da opção pela organização federativa e, ao mesmo tempo, uma confirmação da união de todos os Estados brasileiros sob a mesma Constituição.

\section{A Constituição de 1937}

Os fatos políticos ocorridos no Brasil depois de 1934 mostram que a Assembléia Nacional Constituinte pode ter sido, efetivamente, muito mais a exigência de algumas lideranças políticas poderosas do que do povo brasileiro. Na realidade, o 
povo, em sua grande maioria, tinha mais razões para estar satisfeito com o Governo provisório do que para lamentar a queda do anterior Governo constitucional. O que todos sabiam é que havia corrupção administrativa, favorecimento de amigos e correligionários, falsidade eleitoral, além de muitos privilégios estabelecidos por lei em benefício das elites sociais e econômicas, que representavam não mais do que dez por cento da população. As relações de trabalho eram injustas e não havia proteção para os direitos dos trabalhadores. Além disso, as mulheres não tinham o gozo de direitos políticos e estavam impedidas de ter acesso aos cargos públicos de maior importância. Tudo isso começava a ser mudado e o Governo encontrava facilidade para introduzir as inovações, porque o Parlamento tinha sido dissolvido e não havia oposição ativa, a não ser por meio de alguns jornais que atingiam pequeníssima parte do povo.

Um fato político de grande importância, com graves conseqüências no futuro imediato, foi a decisão da Assembléia Constituinte de eleger o primeiro presidente da República a ser escolhido depois de promulgada a Constituição, repetindo o que tinha feito a Constituinte de 1891 . O presidente eleito pelos constituintes foi justamente o chefe do Governo provisório, Getúlio Vargas, o que demonstra que ele gozava de prestígio popular e estava sendo considerado um bom governante. É evidente que essa decisão dos constituintes foi produto, também, da habilidade política de Getúlio Vargas, que seria várias vezes comprovada até sua trágica morte, por suicídio, em 1955, quando ele ocupava outra vez a Presidência da República, eleito pelo povo.

Após a promulgação da Constituição de 1934, o Parlamento e os partidos políticos voltaram a funcionar normalmente. Na seqüência do ambiente de euforia política provocado pela Constituinte, duas organizações políticas radicais passaram a agir intensamente: o Partido Comunista e a Ação Integralista. Houve conflitos violentos nas ruas e foi sendo criado um clima de temor e insegurança. No ano de 1935, o Governo federal anunciou ter descoberto e desmantelado um plano dos comunistas para o assassinato simultâneo de chefes militares, em vários pontos do País, e para a imediata tomada do poder pelas armas. Houve muitas prisões e o presidente da República obteve a concordância do Congresso Nacional para assumir poderes excepcionais e suspender garantias constitucionais. No ano de 1937, valendo-se da situação de instabilidade e supervalorizando o "perigo comunista". que aterrorizava as elites sociais, os grandes proprietários e a Igreja católica, Getúlio Vargas conseguiu o apoio de praticamente todos os governadores dos Estados para implantar um sistema ditatorial, que denominou "Estado Novo" 
Para formalizar a implantação do novo sistema, o presidente Getúlio Vargas publicou um decreto, revogando a Constituição de 1934 e publicando uma nova, preparada em segredo por juristas de sua confiança, contendo o seguinte:

\section{Preâmbulo}

O presidente da República dos Estados Unidos do Brasil: atendendo às legítimas aspirações do povo brasileiro à paz política e social, profundamente perturbada por conhecidos fatores de desordem, resultantes da crescente agravação dos dissídios partidários, que uma notória propaganda demagógica procura desnaturar em luta de classes, e da extremação de conflitos ideológicos, tendentes, pelo seu desenvolvimento natural, a resolver-se em termos de violência, colocando a Nação sob a funesta iminência da guerra civil;

Atendendo ao estado de apreensão criado no País pela infiltração comunista, que se torna dia a dia mais extensa e mais profunda, exigindo remédios de caráter radical e permanente;

Atendendo a que, sob as instituições anteriores, não dispunha o Estado de meios normais de preservação e de defesa da paz, da segurança e do bem-estar do povo;

Com o apoio das forças armadas e cedendo às inspirações da opinião nacional, umas e outras justificadamente apreensivas diante dos perigos que ameaçam a nossa unidade e da rapidez com que se vem processando a decomposição das nossas instituições civis e políticas;

Resolve assegurar à Nação a sua unidade, o respeito à sua honra e à sua independência, e ao povo brasileiro, sob um regime de paz politica e social, as condições necessárias à sua segurança, ao seu bem-estar e à sua prosperidade, decretando a seguinte Constituição, que se cumprirá desde hoje em todo o País: Constituição dos Estados Unidos do Brasil.

Antes de tudo, o texto publicado pelo decreto de Getúlio Vargas não era, evidentemente, uma autêntica e legítima constituição, não sendo mais do que uma imposição ditatorial. A última frase do Preâmbulo deixa evidente esse caráter, quando determina o cumprimento imediato das regras contidas naquele texto, que só representava a vontade do ditador. Além disso, num dos últimos artigos dessa falsa constituição estava disposto que ela seria submetida ao povo, para que fosse referendada, o que, na realidade, jamais ocorreu, embora Getúlio Vargas tenha permanecido no Governo até 1945, quando foi destituído por um movimento político-militar. 
Esse Preâmbulo, em síntese, é apenas um manifesto político, por meio do qual o ditador procura convencer o povo, sobretudo as camadas superiores que tinham interesse na conservação de seus privilégios e temiam a perda de seu patrimônio, de que as violências políticas tinham criado o risco de uma guerra civil. Denunciando a infiltração comunista crescente, chama a atenção para o "perigo comunista" - o mesmo argumento que seria utilizado em 1964 para a implantação de outra ditadura e conclui que se tornava indispensável o estabelecimento de novas instituições, porque as que existiam não davam ao Estado os meios necessários para garantir a paz e o bem-estar do povo.

Note-se que o Preâmbulo não faz referência aos partidos políticos, dando como justificativa para o decreto ditatorial as "inspirações da opinião nacional" expressão vaga que procura ocultar o fato de que não houve consulta a qualquer órgão representativo ou entidade que expressasse a vontade e os interesses da população. Houve, sim, o apoio das forças armadas, expressamente mencionado no Preâmbulo, mas isso, evidentemente, não pode ser confundido com a manifestação da concordância do povo nem legitima um golpe de Estado. Apesar dos artifícios retóricos, o Preâmbulo deixa claro que estava sendo implantada uma ditadura e que esta procurava disfarçar sua verdadeira natureza escondendo-se atrás de um texto que foi chamado impropriamente de Constituição.

\section{A Constituição de 1946}

A ditadura de Getúlio Vargas foi a confirmação de que "todas as ditaduras se parecem". Recebida sem entusiasmo e também sem qualquer manifestação vigorosa de oposição, teve um início tranqüilo, entre outras razões pelo fato de que o Congresso Nacional tinha sido fechado no mesmo dia da publicação do decreto implantando a ditadura, os partidos políticos deixaram de existir, foram proibidas as manifestações públicas de caráter político e o Poder Judiciário estava impedido de assegurar os direitos fundamentais.

Durante esse período ditatorial foi modernizada a Adıninistração Pública, introduziu-se o planejamento no setor público, procurou-se racionalizar o sistema tributário e o Estado começou a ter presença mais forte na sociedade brasileira, inclusive dando apoio às atividades econômicas básicas. A par disso, desenvolveu-se uma organização sindical, protegida pelo Estado. Entretanto, como sempre acontece nas ditaduras, todas as formas de oposição foram proibidas, criando-se um aparato de vigilância e segurança, que agia arbitrariamente, sem regras nem limitações legais. Foi criada uma Polícia Especial para dissolver manifestações públicas de caráter 
oposicionista, praticando-se violências, prisões ilegais e tortura, instalando-se um tribunal especial para os casos de segurança nacional. Os governos dos Estados foram entregues a Interventores, que eram meros agentes do Governo central, sem autonomia. Na Administração Pública instalou-se uma casta privilegiada, comandada por amigos e fiéis seguidores do ditador. O sistema sindical descambou para um sindicalismo controlado pelo Ministério do Trabalho.

Adotando uma atitude populista, Getúlio Vargas procurava aparecer perante a opinião pública como "pai dos pobres", preocupado com o bem-estar dos trabalhadores e a assistência às camadas mais pobres da população. Desenvolveu-se o culto da personalidade e em todas as repartições públicas era obrigatória a colocação de uma fotografia do ditador em lugar de destaque. Nas escolas os estudantes eram treinados para elogiar “o presidente Getúlio Vargas” como o grande benfeitor da Pátria. Coroando tudo isso, foi estabelecido um rígido sistema de censura da Imprensa, comandado pelo Departamento de Imprensa e Propaganda.

Após a èclosão da segunda guerra mundial, Getúlio Vargas tomou atitude ambígua, deixando intervir que tinha mais simpatia pelo nazifascismo. Entretanto, o afundamento de alguns navios mercantes brasileiros, atribuído a submarinos alemães que visavam impedir que o Brasil suprisse os Aliados anti-nazistas e anti-fascistas de bens essenciais e matéria-prima de caráter estratégico, tornou inevitável a entrada do Brasil na guerra, ao lado dos Aliados. Nesse ambiente, favorecido pelas circunstâncias, Getúlio Vargas construiu uma grande usina siderúrgica, que foi de grande importância para o desenvolvimento do parque industrial brasileiro, e iniciou a exploração do petróleo, o que também favoreceu muito a economia brasileira.

Terminada a guerra, os militares brasileiros que tinham convivido com os militares dos países que defendiam a democracia juntaram-se à oposição democrática, que, embora impedida de se organizar e de manifestar se publicamente, já era muito forte no Brasil. Assim, em 1945, Getúlio Vargas foi tirado do Governo, sem que houvesse luta, iniciando-se a redemocratização do país. Um Governo provisório convocou uma Assembléia Nacional Constituinte, partidos Políticos foram rapidamente organizados sem qualquer restrição ideológica, num espectro que incluía partidos ultraconservadores, outros moderados e também adeptos da esquerda mais extremada, como o Partido Comunista. Adotou-se um sistema eleitoral democrático, com voto secreto e ampla extensão dos direitos políticos, ficando excluídos, entretanto, os analfabetos.

Instalada a Assembléia Constituinte, seus trabalhos foram desenvolvidos num ambiente de entusiasmo pelo restabelecimento da liberdade e pela possibilidade 
de implantação de uma ordem jurídica democrática. Desse modo, no ano de 1946, após alguns meses de intensa atividade, foi aprovada a nova Constituição, com o seguinte:

\section{Preâmbulo}

Nós, os representantes do povo brasileiro, reunidos sob a proteção de Deus, em Assembléia Constituinte para organizar um regime democrático, decretamos e promulgamos a seguinte Constituição dos Estados Unidos do Brasil.

Como se verifica, os constituintes de 1946 optaram por um breve Preâmbulo, reproduzindo, quase na íntegra, o Preâmbulo da Constituição de 1934 . Foi lembrada a condição de representantes do povo, que dava legitimidade aos constituintes e à Constituição por eles aprovada. Mais uma vez foi invocada a proteção de Deus, sendo oportuno lembrar que já se iniciativa a disputa entre o sistema capitalista e o comunismo soviético, continuando a existir no Brasil o pavor do comunismo, apresentado como o anti-cristo, o inimigo da liberdade e da propriedade privada. Reafirmou-se que a Assembléia Constituinte tinha sido convocada para organizar um regime democrático, mas a predominância de conservadores e liberais burgueses, contrários à intervenção do Estado e à extensão dos direitos sociais, fez com que não se fizesse a enumeração de objetivos específicos. Afirmou-se que a liberdade estava implícita na afirmação do caráter democrático do regime, considerando-se, por outro lado, que a referência à "Justiça e o bem-estar social e econômico" seria uma concessão às propostas socialistas e, em última análise, poderia servir de apoio a um avanço comunista.

Finalmente, foi adotada a fórmula "Estados Unidos do Brasil" para reafirmar a opção pela organização federativa. Não houve menção à República nesse Preâmbulo, porque se considerou que, sendo democrático o regime, estaria implícita a preservação do sistema republicano, além do que naquela Constituinte não houve reivindicações monarquistas. Direitos e garantias fundamentais foram suspensos e se instalou uma ditadura, parecida com todas as outras, com violências, prisões arbitrárias, tortura, corrupção e favoritismo. Na realidade, a constituição deixou de existir como verdadeira Constituição com a publicação do Ato Institucional, pois já não tinha a eficácia de norma superior. Vieram depois outros comandos militares, denominados Atos Institucionais ou Atos Complementares, determinações arbitrárias sem qualquer legitimidade impostas como leis superiores.

Com a intenção de criar uma aparência de legitimidade e de normalidade constitucional, o general, que ocupava a Presidência da República, enviou ao Congresso 
Nacional um projeto de Constituição. É importante esclarecer que o Congresso Nacional tinha sido fechado pela força e foi depois reaberto, mas muitos de seus membros, eleitos pelo povo, tiveram arbitrariamente caçados seus mandatos e o Congresso, órgão do Poder Legislativo, estava proibido de "contestar o regime" e de discutir os Atos Institucionais e Complementares, devendo subordinar-se a eles.

Como se pode imaginar, o Congresso aprovou formalmente o texto enviado pelo general-presidente e assim foi aprovada e publicada a Constituição de 1967, com o seguinte:

Preâmbulo

O Congresso Nacional, invocando a proteção de Deus, decreta e promulga a seguinte Constituição do Brasil.

Os próprios termos do Preâmbulo deixam expressa a falta de legitimidade da Constituição aprovada em 1967. Se estava em vigor a Constituição de 1946, como foi dito no Ato Institucional, não tinha base jurídica un ato do Congresso Nacional que só tinha competência para fazer leis ordinárias e complementares e para aprovar emendas constitucionais, mas sempre subordinado às normas da Constituição. $\mathrm{O}$ Congresso Nacional não tinha sido eleito com os poderes de Assembléia Constituinte e assim tanto o Preâmbulo quanto a pretensa constituição a que ele se refere, não têm consistência e não valem juridicamente.

Assim, pois, esse é um falso Preâmbulo de uma falsa Constituição. A referência expressa ao Congresso Nacional é uma confissão da ilegitimidade, a invocação à proteção de Deus é simples fórmula retórica, pois naquele momento

\section{A Constituição de 1967}

Embora no Preâmbulo da Constituição de 1946 não houvesse menção à Justiça e ao bem-estar social e econômico, durante sua vigência houve consideráveis avanços no sentido da democratização da sociedade brasileira, bem como da maior eficácia da Constituição. Assim, foi restabelecida a autonomia dos Estados-membros e dos Municípios, os direitos trabalhistas tiveram aplicação efetiva e em vários aspectos importantes foram ampliados, em grande parte graças ao surgimento de um sindicalismo autêntico, livre do controle do Governo. O dado político mais ambíguo foi a extinção do Partido Comunista por um ato do Governo, fortemente influenciado pela Igreja católica. $\mathrm{O}$ argumento que se usou para justificar esse ato foi que a existência de um Partido Comunista seria incompativel com o regime democrático, identificado com o 
capitalismo. Esse argumento foi acolhido pelo Supremo Tribunal Federal, devendo-se também assinalar que grande parte da população tinha pavor do comunismo e concordou com as ações do Governo, visando coibir qualquer manifestação comunista.

A partir do final da Segunda Guerra Mundial, em grande parte sob influência da propaganda e das tentativas de expansão da União Soviética, a questão dos direitos sociais e econômicos passou a ter grande ênfase nos debates sobre democracia e Justiça social. A aprovação da Declaração Universal dos Direitos Humanos pela Organização das Nações Unidas, em 1948, foi o ponto de partida para uma intensificação das ações em favor daqueles direitos, bem como de outros direitos fundamentais, como a liberdade e a igualdade. Esses movimentos tiveram repercussão no Brasil, onde surgiram várias organizações católicas tendo por objetivo lutar pela superação das injustiças, tendo sido criadas com esse propósito, entre outras, uma organização denominada Juventude Universitária Católica, JUC e outra chamada Juventude Operária Católica, JOC. No quadro do sindicalismo operário surgiram lideranças socialistas e comunistas que também seguiam essa linha.

A partir de 1959, com o êxito da Revolução Cubana, esse debate foi intensificado no Brasil, onde muitos estavam convencidos de que a interferência do capitalismo internacional, especialmente dos EUA, era um obstáculo à Justiça social. Aplaudidos com entusiasmo, Fidel Castro e o "Che" Guevara estiveram no Brasil e foram condecorados pelo Governo Federal brasileiro, o que foi recebido com entusiasmo por muitos militantes políticos, inclusive por pessoas ostensivamente contrárias ao comunismo. Houve, entretanto, reações indignadas de parlamentares dos partidos de direita ou conservadores, bem como de militares convencidos de que o comunismo ameaçava a liberdade e a soberania nacional, de empresários que viam ameaçadas a liberdade econômica e a propriedade privada e, sobretudo, dos bispos mais influentes na hierarquia católica, o que repercutiu fortemente entre os católicos de todo o País.

Em setembro de 1961 o presidente da República, Jânio Quadros, que tinha sido eleito no final de $1960 \mathrm{com}$ grande maioria de votos, mas enfrentava forte oposição no Congresso Nacional, renunciou ao mandato sem ter sofrido qualquer coação para isso, tudo levando a crer que sua intenção era provocar a ida do povo para as ruas pedindo sua volta, dando-lhe condições para assumir plenos poderes. $\mathrm{O}$ povo ficou indignado com a renúncia do presidente e não foi para as ruas. Em consequiência, assumiu a Presidência da República o vice-presidente, João Goulart, afilhado de Getúlio Vargas, ligado ao trabalhismo, mas sem grande preparo e sem autoridade política, acusado de ser muito ligado às lideranças sindicais comunistas. Num primeiro momento 
os militares se opuseram à posse de Goulart na Presidência, mas acabaram concordando desde que o sistema presidencial de Governo fosse substituído pelo parlamentarismo, o que foi feito mediante emenda constitucional, havendo uma acomodação apenas aparente.

No dia $1^{\circ}$. de abril de 1964 um golpe militar destituiu João Goulart e a Presidência da República foi entregue a um militar, o general Castelo Branco. Nesse mesmo momento os chefes militares publicaram um documento intitulado Ato Institucional, declarando que continuava em vigor a Constituição de 1946, mas que em caso de conflito de normas deveria sempre prevalecer o Ato Institucional. Direitos e garantias fundamentais foram suspensos e se instalou uma ditadura, parecida com todas as outras, com violências, prisões arbitrárias, tortura, corrupção e favoritismo. Na realidade, a constituição deixou de existir como verdadeira Constituição com a publicação do Ato Institucional, pois já não tinha a eficácia de norma superior. Vieram depois outros comandos militares, denominados Atos Institucionais ou Atos Complementares, determinações arbitrárias sem qualquer legitimidade impostas como leis superiores.

Com a intenção de criar uma aparência de legitimidade e de normalidade constitucional, o general, que ocupava a Presidência da República, enviou ao Congresso Nacional um projeto de Constituição. É importante esclarecer que o Congresso Nacional tinha sido fechado pela força e foi depois reaberto, mas muitos de seus membros, eleitos pelo povo, tiveram arbitrariamente caçados seus mandatos e o Congresso, órgão do Poder Legislativo, estava proibido de "contestar o regime" e de discutir os Atos Institucionais e Complementares, devendo subordinar-se a eles.

Como se pode imaginar, o Congresso aprovou formalmente o texto enviado pelo general-presidente e assim foi aprovada e publicada a Constituição de 1967, com o seguinte:

Preâmbulo

O Congresso Nacional, invocando a proteção de Deus, decreta e promulga a seguinte Constituição do Brasil.

Os próprios termos do Preâmbulo deixam expressa a falta de legitimidade da Constituição aprovada em 1967. Se estava em vigor a Constituição de 1946, como foi dito no Ato Institucional, não tinha base jurídica um ato do Congresso Nacional que só tinha competência para fazer leis ordinárias e complementares e para aprovar emendas constitucionais, mas sempre subordinado às normas da Constituição. $\mathrm{O}$ 
Congresso Nacional não tinha sido eleito com os poderes de Assembléia Constituinte e assim tanto o Preâmbulo quanto a pretensa constituição a que ele se refere, não têm consistência e não valem juridicamente.

Assim, pois, esse é um falso Preâmbulo de uma falsa Constituição. A referência expressa ao Congresso Nacional é uma confissão da ilegitimidade, a invocação à proteção de Deus é simples fórmula retórica, pois naquele momento nem o povo nem a Igreja católica tinham condições para influenciar uma decisão política do comando militar, verdadeiro autor do novo texto apresentado como Constituição. E a referência sintética à "Constituição do Brasil" deixou evidente que não se pretendia respeitar os preceitos do federalismo, pois todos os governantes, órgãos e administradores públicos estavam subordinados às determinações arbitrárias do comando militar superior.

\section{A Constituição de 1969}

Como é regra nas ditaduras, em 1969 a Imprensa estava rigorosamente censurada, qualquer manifestação pública de caráter político que pudesse ser interpretada como crítica ao Governo seria enquadrada como crime e as decisões do comando militar superior eram tomadas em segredo. Por todos esses motivos, embora muita gente tivesse a convicção de que havia divergências entre os militares que dominavam politicamente o Brasil, foi com surpresa que o povo brasileiro recebeu do comando militar a informação de que o Brasil passava a ter uma nova Constituição.

Na realidade, o que se comunicou foi que o texto da Constituição de 1967 estava sendo substituído por outro, que recebeu a denominação de "Emenda Constitucional número 1" e que, na realidade, alterava grande parte do texto de 1967, restringindo ainda mais os direitos e alterando outros pontos substanciais. $\mathrm{O}$ novo texto, que na prática é geralmente referido como Constituição de 1969, foi publicado com o seguinte:

\section{Preâmbulo}

Os ministros da Marinha, de Guerra, do Exército e da Aeronáutica Militar, usando das atribuições que lhes confere $\mathrm{o}$ artigo $3^{\circ}$. do Ato Institucional número 16, de 14 de outubro de 1969 , combinado com o parágrafo $1^{\circ}$ do artigo $2^{\circ}$ do Ato Institucional número 5, de 13 de dezembro de 1968,e,

Considerando que, nos termos do Ato Complementar n. 38, de 13 de dezembro de 1968, foi decretado, a partir dessa data, o recesso do Congresso Nacional; 
Considerando que, decretado o recesso parlamentar, o Poder Executivo Federal fica autorizado a legislar sobre todas as matérias, conforme o disposto no $\$ 1^{\circ}$ do art. $2^{\circ}$. do Ato Institucional n. 5, de 13 de dezembro de 1968;

Considerando que a elaboração de emendas à Constituição, compreendida no processo legislativo (art. 49, I), está na atribuição do Poder Executivo Federal;

Considerando que a Constituição de 24 de janeiro de 1967, na sua maior parte, deve ser mantida, pelo que, salvo emendas de redação, continuam inalterados os seguintes dispositivos;

Considerando as emendas modificativas e supressivas que, por esta forma, são ora adotadas quanto aos demais dispositivos da Constituição, bem como as emendas aditivas que nela são introduzidas;

Considerando que, feitas as modificações mencionadas, todas em caráter de Emenda, a constituição poderá ser editada de acordo com o texto que adiante se publica,

Promulgam a seguinte Emenda à Constituição de 24 de janeiro de 1967:

O Congresso Nacional, invocando a proteção de Deus, decreta e promulga a seguinte Constituição da República Federativa do Brasil.

Os termos do Preâmbulo não deixam dúvida de que se trata de um ato ditatorial, desprovido de valor jurídico, contendo mesmo alguns absurdos que vale a pena ressaltar. Em primeiro lugar, os três ministros militares que assinam texto invocam, como fundamento para o seu ato, os Atos Institucionais, isto é, comandos militares arbitrários anteriores e não a Constituição, o que, obviamente, significa uma autolegitimação, ou seja, nenhuma legitimação.

A segunda pérola é a afirmação de que, tendo um Ato Institucional determinado o fechamento do Congresso Nacional, em 1968, o Poder Executivo Federal ficava autorizado a legislar sobre todas as matérias. Essa atribuição de competência legislativa plena ao Poder Executivo, como decorrência do ato de força que determinou o fechamento do Congresso, já seria um absurdo, mas o absurdo é ainda maior quando pretendem confundir três ministros militares com o Poder Executivo. Em seguida se diz que a elaboração de emendas à Constituição, compreendida no processo legislativo, está na atribuição do Poder Executivo Federal. O que a Constituição estabelecia era que o presidente da República, não o Poder Executivo ou os ministros militares, poderia fazer o encaminhamento de propostas de emenda constitucional ao Congresso Nacional. Como é evidente, encaminhar uma proposta de emenda é bem diferente de elaboração de emendas e imposição delas sem discussão nem votação no Congresso. 
Afinal, reconhecendo que eram tantas as emendas que o resultado era um texto novo, o Preâmbulo acrescenta, ambiguamente, que " $a$ Constituição poderá ser editada de acordo com o texto que adiante se publica" Qualquer pessoa que tenha algum conhecimento de Direito Constitucional sabe que, aprovada uma emenda constitucional, ela se incorpora ao texto existente, não sendo necessária nova publicação formal da integra do texto constitucional. Em resumo, esse Preâmbulo é importante por ser um reconhecimento expresso de que o texto da constituição de 1969 era apenas uma farsa, procurando ocultar, sem sucesso, a realidade da ditadura.

\section{III . A Constituição brasileira de 1988}

As violências e arbitrariedades, a corrupção, o favoritismo e outras práticas antidemocráticas que caracterizaram o regime militar implantado em 1964 levaram ao seu esgotamento. No final da década de 70 já não havia condições políticas para a manutenção daquele regime, pois grande parte da população que o apoiara no início já reconhecia que a alegação da necessidade de proteção da liberdade, dos direitos fundamentais e dos valores cristãos tinha sido enganosa. As imposições ditatoriais, a negação dos direitos, as prisões ilegais, as invasões arbitrárias de residências de oposicionistas, a prática de tortura, bem como a criação de uma casta privilegiada envolvida em corrupção, nada disso confirmava o propósito de salvar o Brasil do perigo do comunismo e resguardar os direitos e valores fundamentais do povo brasileiro. Por tudo isso foi crescendo internamente um movimento, unindo no mesmo propósito muitas organizações de espécies diferentes e envolvendo quase todo o povo, exigindo a redemocratização do País. A repercussão internacional negativa de tudo o que vinha acontecendo no Brasil também influiu para que ficasse insustentável o regime militar.

Assim, no final da década de 60 teve início o retorno à normalidade constitucional. O Congresso Nacional, acrescido de mais algumas pessoas ocupantes de altos cargos públicos, compôs um colégio eleitoral, que elegeu um civil para a Presidência da República e este, depois de superadas algumas dificuldades imprevistas, enviou projeto de emenda constitucional ao Congresso, propondo que o Congresso Nacional a ser eleito logo em seguida tivesse poderes para elaborar uma nova Constituição. Não era a fórmula ideal, pois o que muitos queriam era uma Assembléia Nacional Constituinte, que seria eleita pelo povo com a finalidade exclusiva de elaborar uma Constituição. Mas as condições políticas ainda eram dificeis e o povo e as lideranças políticas queriam que o Brasil retornasse à normalidade democrática e constitucional o mais rápido possível. Por isso foi aceita e aplicada a fórmula proposta e o povo elegeu 
deputados e senadores que integrariam o Congresso Nacional, que antes de começar a atuar como Poder Legislativo teria a função de Assembléia Nacional Constituinte.

Houve ampla liberdade para a organização de partidos políticos, o processo eleitoral desenvolveu-se com ampla liberdade, procedendo-se à eleição e sendo imediatamente iniciado o trabalho de elaboração da nova Constituição. Um dado muito importante e altamente positivo foi o intenso envolvimento do povo nos trabalhos da Constituinte, que, entre outras coisas, admitiu que um certo número de eleitores apresentasse emendas ao Projeto de Constituição, tendo havido muitas propostas de origem popular, influindo nas decisões dos representantes. Além disso, muitas organizações representativas dos mais diversos interesses e de todas as camadas da população mantiveram permanente contacto com os constituintes, oferecendo sugestões, fazendo críticas, defendendo certas propostas e manifestando oposição a outras. Afinal, em 1988, foi aprovada a nova Constituição do Brasil, atualmente em vigor, com o seguinte:

\section{Preâmbulo}

Nós, representantes do povo brasileiro, reunidos em Assembléia Nacional Constituinte para instituir um Estado Democrático, destinado a assegurar o exercício dos direitos sociais e individuais, a liberdade, a segurança, o bem-estar, o desenvolvimento, a igualdade e a Justiça como valores supremos de uma sociedade fraterna, pluralista e sem preconceitos, fundada na harmonia social e comprometida, na ordem interna e internacional, com a solução pacífica das controvérsias, promulgamos, sob a proteção de Deus, a seguinte Constituição da República Federativa do Brasil.

O Preâmbulo começa ressaltando o fato de que a Constituição foi elaborada por representantes do povo, reunidos em Assembléia Nacional Constituinte, o que era muito importante, naquela circunstância, para deixar bem evidente que era o povo quem estava decidindo, através de seus representantes e pelo método reconhecido como essencialmente democrático, que é a Assembléia Nacional Constituinte.

O que vem em seguida é uma afirmação muito clara de compromisso com as exigências dos Direitos Humanos, constantes da Declaração Universal de 1948 , dos Pactos de Direitos Humanos aprovados pela ONU, em 1966, e de muitos outros documentos básicos que compõem o acervo normativo dos Direitos Humanos que hoje vem determinando os rumos para a criação de uma nova sociedade, livre, justa e regida pelo Direito. Assim é que, depois de ressaltar que o objetivo da Assembléia Nacional 
Constituinte era instituir um Estado Democrático, o Preâmbulo faz duas enumerações, uma referente aos direitos e valores fundamentais e outra relativa ao tipo de sociedade que os constituintes, expressando a vontade do povo, tiveram em mira.

Na primeira enumeração indica-se como objetivo "assegurar o exercicio dos direitos sociais e individuais, a liberdade, a segurança, o bem-estar, o desenvolvimento, a igualdade e a Justiça". É muito importante notar que o Preâmbulo fala em assegurar o exercício dos direitos, o que tem significação mais concreta do que uma simples declaração dos direitos, sem preocupação com seu exercício. A segunda enumeração refere-se ao tipo de sociedade que se pretende atingir e manter com base na Constituição, ou seja, "uma sociedade fraterna, pluralista e sem preconceitos, fundada na harmonia social". A esses direitos, valores e objetivos característicos de uma sociedade democrática se acrescenta o comprometimento, na ordem interna e internacional, com a solução pacífica das controvérsias, rejeitando-se os métodos violentos a que muitas vezes recorrem os Estados ou grupos organizados, quando usam a guerra, a repressão violenta ou a prática de terrorismo como instrumentos de superação de conflitos, de controle social ou de preservação de interesses, o que, na realidade, leva sempre ao aumento da violência e não à preservação dos direitos e à conquista da paz.

Depois disso, invocando a proteção de Deus, o que é um sinal de que a maioria dos constituintes estava convencida de que o povo brasileiro rejeita ambas as espécies de materialismo de que fala o papa João Paulo II na encíclica "Laborem Exercens" isto é, o materialismo teórico do marxismo e o marxismo prático inerente ao capitalismo. Por último, o Preâmbulo insere a expressão "República Federativa do Brasil" deixando expressas as opções pelo sistema republicano e pela organização federativa do Estado.

O Preâmbulo da atual Constituição brasileiro é bem adequado a uma Constituição democrática, segundo as modernas concepções. Ele ressalta que a Constituição foi elaborada por processo democrático, mas acrescenta que a Constituição é um instrumento para a consecução de objetivos fundamentais da pessoa humana e de toda a Humanidade. Um dado final que tem grande importância é que na obra de vários constitucionalistas brasileiros contemporâneos, assim como na jurisprudência, já é referido o Preâmbulo como norma constitucional, de eficácia jurídica plena e condicionante da interpretação e da aplicação das normas constitucionais e de todas as normas que integram o sistema jurídico brasileiro.

Uma constatação preocupante é que os principais órgãos do Estado brasileiro responsáveis pela guarda e aplicação dos mandamentos constitucionais, aí 
incluindo o Congresso Nacional, a Presidência da República e o Supremo Tribunal Federal, não vêm mantendo estrito respeito à constituição e várias vezes, por ação ou omissão, tomaram posição contrária ao que ela determina. Mas a constatação, indiscutivel, de que essa é uma constituição verdadeiramente democrática, a mais democrática que o Brasil já teve, alimenta a esperança de que ela resista às agressões e tenha plena e efetiva aplicação, atuando eficazmente como instrumento de garantia da liberdade, de proteção da dignidade humana, de promoção de Justiça, de consecução da paz.

São Paulo, maio de 2001. 
Bibliografia

BARBALHO, João, Constituição Federal Brasileira, Rio de Janeiro, F.Briguiet, 1924.

CAVALCANTI, Themístocles B., A Constituição Federal Comentada, Rio de Janeiro, José Konfino, 1951.

DUARTE, José, A Constituição Brasileira de 1946, Rio de Janeiro, Imprensa Nacional, 1948.

FERREIRA, Pinto, Princípios Gerais do Direito Constitucional Moderno(2vols) São Paulo, Saraiva, 1983.

HORTA, Raúl Machado, Estudos de Direito Constitucional, Belo Horizonte, Del Rey, 1995.

LEAL, Aurelino, História Constitucional do Brasil, Rio de Janeiro, Imprensa Nacional, 1915.

PIMENTA BUENO, José Antônio, Direito Público Brasileiro e Análise da Constituição do Império, Brasília, Senado Federal, 1978

SILVA, José Afonso da, Curso de Direito Constitucional Positivo, São Paulo, Revista dos Tribunais, 1991.

SOARES, Orlando, Comentários à Constituição da República Federativa do Brasil, Rio de Janeiro, Forense, 1999. 